\title{
TRWAŁOŚĆ EKONOMICZNA GOSPODARSTW EKOLOGICZNYCH W LATACH 2010-2013*
}

Wedtug „Raportu o stanie rolnictwa ekologicznego $w$ Polsce $w$ latach 2013-2014” wydanego przez IJHARS (www.ijhar-s.gov.pl), produkcje wyłacznie $w$ systemie ekologicznym prowadziło $w$ tych latach odpowiednio 67 i $60 \%$ gospodarstw ekologicznych. Pozostaty odsetek tych gospodarstw to podmioty realizujace produkcję rolna zarówno wedtug metod ekologicznych jak $i$ konwencjonalnych. Jak wykazały badania prowadzone w systemie Polski FADN, gospodarstwa te różniq się znacznie od siebie pod względem organizacyjnym, produkcyjnym, ekonomicznym. Gospodarstwa stosujace wyłącznie metody ekologiczne wyróżnia bardziej holistyczne podejście do realizowanej działalności rolniczej, sa one bardziej wiarygodne pod wzgledem jakości wytwarzanej żywności ekologicznej, ale uzyskują słabsze efekty ekonomiczne. Potwierdza to niniejsze opracowanie, traktujace o organizacji, wynikach produkcyjno-ekonomicznych takich gospodarstw, pogrupowanych według przedziałów obszarowych użytków rolnych. Badania dowiodty, że ich efekty produkcyjne na przestrzeni kilku lat byty dość podobne i malały ze wzrostem obszarowym gospodarstw, jednocześnie jednak zmniejszała sie intensywność produkcji. Produkcje ograniczała też bardzo niska jakość gleb. Analiza wskazała na słabość produkcyjna i ekonomiczna tych gospodarstw, ogromne uzależnienie od dopływu dopłat i raczej niewielkie szanse rozwoju w nadchodzacych latach.

Słowa kluczowe: gospodarstwo ekologiczne, ekologiczny system produkcji, rolnictwo ekologiczne, intensywność produkcji ekologicznej, dopłaty ekologiczne, efektywność produkcji, dochód, rynek żywności ekologicznej, produktywność ziemi

\footnotetext{
* Opracowanie dotyczy gospodarstw ekologicznych stosujących wyłącznie ekologiczne metody produkcji. Rozporządzenie Rady (WE) nr 834/2007 z dnia 28 czerwca 2007 r. w sprawie produkcji ekologicznej i znakowania produktów ekologicznych dopuszcza funkcjonowanie gospodarstw mieszanych, czyli stosujących w jednym obiekcie zarówno ekologiczne, jak i konwencjonalne metody produkcji.
} 


\section{Wprowadzenie}

Ponad 10-letni okres uczestniczenia Polski we Wspólnej Polityce Rolnej był dla rolnictwa ekologicznego czasem znaczącego rozwoju. Ministerstwo Rolnictwa i Rozwoju Wsi (MRiRW) przewiduje dalszy rozwój tego segmentu rolnictwa, wzrost jego konkurencyjności, wzrost podaży żywności ekologicznej na rynku ${ }^{1}$. Spełnienie tych zamierzeń zależy w dużym stopniu od trwałości gospodarstw, ich nieprzerwanego, świadomego uczestniczenia w tym systemie. Uwarunkowane jest to przede wszystkim opłacalnością ekonomiczną produkcji, jej konkurencyjnością wobec produkcji realizowanej metodą konwencjonalną, uniezależnieniem funkcjonowania gospodarstw od dopływu dopłat.

Zdolność konkurowania gospodarstw rolnych zależy w dużej mierze od stanu zasobów gospodarstwa, między innymi ilości i jakości ziemi, zasobów majątkowych i finansowych, potencjału czynnika ludzkiego (wiedzy, umiejętności, determinacji w dążeniu do celu). Konsekwencją konkurencyjności gospodarstwa rolnego wobec innych podobnych podmiotów na rynku jest jego trwałość w dłuższej perspektywie czasu (Józwiak (red.), 2014). Trwałość gospodarstw oznacza ich zdolność nie tylko do bieżącego funkcjonowania, ale także do rozwoju. Warunkiem tego jest odpowiednia efektywność ekonomiczna gospodarstwa, mierzona poziomem dochodu, który powinien zapewnić pokrycie kosztów użycia własnych czynników produkcji (ziemi, kapitału i pracy), ale też umożliwić inwestowanie w nowe aktywa gospodarstwa, a nie tylko reprodukcję majątku (Józwiak (red.), 2014; Ziętara, 2012).

\section{Ogólny obraz polskiego rolnictwa ekologicznego}

Obecnie polskie rolnictwo ekologiczne charakteryzuje duże rozdrobnienie, a więc przede wszystkim małe zasoby ziemi. W roku 2013 niemal 70\% gospodarstw ekologicznych stanowiły podmioty do 20 ha użytków rolnych (UR), a 18,8\% z nich miało poniżej 5 ha UR ${ }^{2}$. Zapewne wiele tych gospodarstw nie podoła konkurencji i odpadnie z sektora rolnictwa ekologicznego. Wydaje się, że proces eliminacji został już zapoczątkowany, jako że w roku 2014 w stosunku do roku 2013 IJHAR-S odnotował kilkuprocentowy spadek liczby gospodarstw do 10 ha UR. Zmniejszyła się też o 1,9\% ogólna powierzchnia użytków rolnych pod uprawami ekologicznymi ${ }^{3}$. Problemem rolnictwa ekologicznego w Polsce jest jednak od lat nie wielkość obszarowa UR, ale stan pogłowia zwierząt. Tempo jego przyrostu było znacznie niższe, nieadekwatne do przyrostu powierzchni użytków rolnych.

Idea rolnictwa ekologicznego polega na łączeniu produkcji roślinnej i zwierzęcej, dążeniu do zachowania równowagi paszowo-nawozowej i stąd potrze-

\footnotetext{
${ }^{1}$ Ramowy Plan Działań dla Żywności i Rolnictwa Ekologicznego w Polsce na lata 2014-2020.

${ }^{2}$ Raport o stanie rolnictwa ekologicznego w Polsce w latach 2013-2014. IJHARS. Warszawa 2015.

${ }^{3}$ http://www.ijhar-s.gov.pl/index.php/raporty-i-analizy.html.
} 
ba udziału zwierząt w gospodarstwie ekologicznym. Służy to właściwemu ukierunkowaniu produkcji, a w rezultacie dostarczaniu surowców i gotowych produktów na rynek. Według „Kryteriów rolnictwa ekologicznego"4 obowiązujących członków Stowarzyszenia Ekoland, chów zwierząt stanowi integralną część gospodarstwa ekologicznego i jest systemowo powiązany z prowadzoną w nim uprawą roślin. W Polsce w licznych przypadkach nie przestrzegano tej zasady. Te gospodarstwa jednak działały zgodnie z litera prawa, gdyż to holistyczne podejście nie jest obowiązkowe z punktu widzenia nadrzędnego unijnego dokumentu odnośnie rolnictwa ekologicznego, jakim jest Rozporządzenie Rady (WE) nr 834/2007.

Brak zwierząt prawdopodobnie umniejsza rolę takich gospodarstw nie tylko w rynku żywności ekologicznej, ale też zaprzecza idei zrównoważenia środowiskowego, które przypisuje się rolnictwu ekologicznemu. Według Zegara, „trudno jednoznacznie ocenić zrównoważenie gospodarstw bez produkcji zwierzęcej ergo nawozów zwierzęcych w dłuższej perspektywie” (Zegar, 2009).

Doświadczenia uczestnictwa w Unii Europejskiej w minionym 10-leciu wskazują, że rolnictwo ekologiczne w Polsce rozwijało się głównie dzięki dostępności dopłat, nie wpłynęło to jednak na wzrost towarowości produkcji rolnictwa ekologicznego (Brodzińska, 2014), rozwój rynku żywności ekologicznej (Pawlewicz i Szamrowski, 2014). Wiadomo też, że niejednokrotnie dopłaty były kierowane do obszarów, na których w rzeczywistości produkcja nie była realizowana (Kociszewski, 2014). Rolnictwo ekologiczne ma być w dalszym ciągu wspierane z budżetu publicznego w ramach Programu Rozwoju Obszarów Wiejskich 2014-2020 (PROW 2014-2020). W kolejnej edycji tego programu zweryfikowano poziom dopłat oraz zakresy degresywności płatności, położono także nacisk na postulowane $\mathrm{W}$ rolnictwie ekologicznym powiązanie produkcji roślinnej ze zwierzęcą, co ma skutkować obowiązkiem ich utrzymywania. Powinno się to przyczynić do poprawy towarowości produkcji, bo jak utrzymuje K. Brodzińska, jej poziom w gospodarstwie ekologicznym uzależniony jest od udziału zwierząt. Niski dotychczas poziom towarowości produkcji ekologicznej skutkował niewielkim udziałem produktów z polskich gospodarstw w rynku żywności ekologicznej (Brodzińska, 2014). W konsekwencji, mała podaż polskich produktów rolnictwa ekologicznego w stosunku do potencjału gospodarstw ekologicznych w Polsce powodowała, że większość żywności ekologicznej była sprowadzana z zagranicy (Pawlewicz i Szamrowski, 2014). Dotychczas chowem zwierząt wielu rolników nie było zainteresowanych, gdyż, jak wykazują badania, liczne gospodarstwa ekologiczne nie prowadzące w ogóle produkcji zwierzęcej uzyskiwały lepsze wyniki ekonomiczne niż te z udziałem zwierząt. Konkurencyjne ekonomicznie były też w rolnictwie ekologicznym gospodarstwa łączące produkcję w systemie ekologicznym i konwencjonalnym w stosunku do gospodarstw z produkcją wyłącz-

\footnotetext{
${ }^{4}$ http://www.ekoland.pl. (Kryteria rolnictwa ekologicznego Stowarzyszenia Ekoland).
} 
nie ekologiczną (Nachtman, 2015). Obostrzenia co do obowiązku utrzymywania zwierząt w gospodarstwach ekologicznych, korzystających z wsparcia w ramach PROW 2014-2020, powinny spowodować wzrost pogłowia zwierząt, ale mogą także skutkować rezygnacją z systemu ekologicznego.

W świetle zarysowanych powyżej problemów rośnie niepewność co do rozwoju produkcji ekologicznej i wzrostu jej podaży na rynku, choć popyt na żywność ekologiczną systematycznie rośnie (Kwasek, 2013). Rozwój rynku żywności ekologicznej opisany w dokumencie „Ramowy Plan Działań dla Żywności i Rolnictwa Ekologicznego w Polsce na lata 2014-2020" zakłada wzrost dopływu tej żywności na rynek i przewiduje, że w roku 2020 wartość tego rynku wyniesie co najmniej 210 mln euro. Wielu ekspertów szacuje dziś, że jego poziom w roku 2015 osiągnie wartość $700 \mathrm{mln} \mathrm{zt}^{5}$, co w przybliżeniu stanowi około 170 mln euro. Gdyby średnioroczne tempo wzrostu tego rynku wynosiło co najmniej 15\%, zgodnie z przyjętym założeniem, rynek żywności ekologicznej powinien przekroczyć znacznie zakładany poziom.

Ważne jest zatem, czy polskie rolnictwo ekologiczne w przyszłości osiągnie założony rozwój tego rynku. Służyć temu powinien wzrost konkurencyjności gospodarstw ekologicznych. Można się pokusić o stwierdzenie, że przede wszystkim powinny to być jednostki prowadzące wyłącznie produkcję ekologiczną na obszarze całego gospodarstwa. Wynika stąd potrzeba pogłębiania wiedzy o sytuacji produkcyjno-ekonomicznej takich gospodarstw ekologicznych. Służyć to może ocenie perspektyw rozwojowych ekologicznego rolnictwa i rynku żywności. Stąd też celem opracowania jest zaprezentowanie efektów gospodarstw ekologicznych, ich organizacji i kosztów działalności na przestrzeni kilku lat i wskazanie szans na rozwój.

\section{Materiał badawczy, zagadnienia metodyczne}

Przedmiotem analizy są certyfikowane gospodarstwa ekologiczne, które prowadziły nieprzerwanie rachunkowość w systemie Polski FADN w latach 2010-2013. Te jednostki realizowały działalność rolniczą wyłącznie metodami ekologicznymi i rozlokowane były na obszarze całego kraju. Z uwagi na ważność takich gospodarstw dla segmentu rolnictwa ekologicznego wyniki zaprezentowano w pięciu przedziałach obszarowych użytków rolnych (UR) i średnio dla zbiorowości. Wyróżniono następujące grupy: od 5 do <= 10 ha („małe” -43 gospodarstwa), od 10 do $<=20$ ha (,średnio-małe" -65 gospodarstw), od 20 do $<=30$ ha (,średnio-duże" - 33 gospodarstwa), od 30 do <= 50 ha (,duże” 30 gospodarstw) i powyżej 50 ha (,,bardzo duże” -21 gospodarstw). Łącznie w badaniu uczestniczyło w każdym roku 196 tych samych gospodarstw.

\footnotetext{
${ }^{5}$ www.portalspozywczy.pl

${ }^{6}$ Nazewnictwo grup według nomenklatury Polskiego FADN. Wyniki Standardowe 2013 uzyskane przez ekologiczne gospodarstwa rolne. Część I. Wyniki Standardowe. Warszawa 2014.
} 
Wyniki takich gospodarstw są publikowane po raz pierwszy i prezentowane są jako średnie arytmetyczne. W opracowaniu przedstawiono stan zasobów i sposób organizacji produkcji, poziom produkcji i kosztów oraz efektywność gospodarowania. Do oceny efektów gospodarowania posłużył dochód z rodzinnego gospodarstwa rolnego (DzRGR). Zdolność badanych gospodarstw do rozwoju oceniono na podstawie wskaźnika dochodu na osobę nieopłaconą w rodzinie rolnika, stanu reprodukcji majątku oraz wypracowanego zysku z gospodarstwa rolnego. Pojęcie zysku z gospodarstwa rolnego rozumiane jest w tym przypadku jako dochód (DzRGR) pomniejszony o opłatę umownych kosztów pracy własnej rolnika i jego rodziny (Goraj i Mańko, 2011).

\section{Omówienie wyników}

Potencjat produkcyjny gospodarstw. Badane gospodarstwa ekologiczne dysponowały dość niskim potencjałem ekonomicznym. Średnio w całej zbiorowości ich wielkość ekonomiczna zawarta była w granicach 22-23 tys. euro $\mathrm{SO}^{7}$ we wszystkich latach badań - tabela 1. Zgodnie z metodyką unijną gospodarstwa te zalicza się do piątej klasy wielkości ekonomicznej (15 tys. $\leq$ euro $<25$ tys.), zatem do gospodarstw o małej sile ekonomicznej ${ }^{8}$. Ta wartość ukształtowana została na skutek małej wielkości ekonomicznej większości analizowanych gospodarstw, gdyż tylko jednostki powyżej 30 ha użytków rolnych (UR) przekroczyły tę średnią. W przedziałach obszarowych najniższą siłą ekonomiczną charakteryzowały się gospodarstwa z najmniejszymi zasobami ziemi; w miarę zwiększania ich powierzchni wzrastała również wielkość ekonomiczna i taka prawidłowość występowała we wszystkich latach badań. Inaczej kształtowały się nakłady pracy. Srednio w całej zbiorowości wynosiły one około 6 AWU na 100 ha UR. Najwyższe były w gospodarstwach „małych” (od 5 do 10 ha) i ,średnio-małych” (od 10 do 20 ha) - w okresie badawczym 2010-2013 wynosiły odpowiednio 20-22 AWU i 13-14 AWU/ 100 ha UR.

Zasoby pracy malały ze wzrostem powierzchni i w gospodarstwach „,bardzo dużych" (powyżej 50 ha UR) wynosiły zaledwie 1,6-1,5 AWU/100 ha UR. Udział pracy najemnej w pracy ogółem wynosił od 3 do $15 \%$ w poszczególnych grupach UR i kształtował się różnie w latach, ale zawsze najniższy był w grupie gospodarstw ,średnio-dużych” (20-30 ha). Wraz ze wzrostem powierzchni UR malała również wartość aktywów na 1 ha UR, choć ulegała wahaniom w latach. W gospodarstwach najmniejszych obszarowo wynosiła 35-40 tys. zł, a w największych 12-14 tys. zł/ha (tabela 1).

\footnotetext{
${ }^{7}$ Standardowa Produkcja (z ang. Standard Output) jest to średnia z 5 lat wartość produkcji określonej działalności produkcji roślinnej lub zwierzęcej, uzyskiwana z 1 ha lub od 1 zwierzęcia w ciągu 1 roku, w przeciętnych dla danego regionu warunkach produkcyjnych.

${ }^{8}$ Współczynniki Standardowej Produkcji „2010” dla celów Wspólnotowej Typologii Gospodarstw Rolnych (Bocian M., Cholewa I., Tarasiuk R., Warszawa 2014).
} 
Tabela 1

Potencjat produkcyjny gospodarstw ekologicznych w latach 2010-2013

\begin{tabular}{|c|c|c|c|c|c|c|c|c|}
\hline Lata & $\begin{array}{l}\text { Grupy } \\
\text { gospo- } \\
\text { darstw }\end{array}$ & $\begin{array}{c}\text { Wielkość } \\
\text { ekono- } \\
\text { miczna } \\
\text { (euro) }\end{array}$ & $\begin{array}{c}\text { Po- } \\
\text { wierzch- } \\
\text { nia } \\
\text { UR } \\
\text { (ha) }\end{array}$ & $\begin{array}{c}\text { Zasoby } \\
\text { pracy } \\
\text { ogółem/ } \\
\text { gospodar- } \\
\text { stwo } \\
(\mathrm{AWU})^{\mathrm{a}}\end{array}$ & $\begin{array}{c}\text { Zasoby } \\
\text { pracy } \\
\text { na } 100 \text { ha } \\
\text { UR } \\
\text { (AWU) }\end{array}$ & $\begin{array}{c}\text { Udział } \\
\text { pracy } \\
\text { najemnej } \\
(\%)\end{array}$ & $\begin{array}{c}\text { Wartość } \\
\text { aktywów } \\
\text { na } 1 \text { ha } \\
\text { UR } \\
\text { (zł) }\end{array}$ & $\begin{array}{c}\text { Wskaźnik } \\
\text { bonitacji } \\
\text { gleb }\end{array}$ \\
\hline \multirow{6}{*}{2010} & Średnio & 23098 & 28,6 & 1,78 & 6,23 & 10,5 & 21017 & 0,60 \\
\hline & $5<\mathrm{ha} \leq 10$ & 11545 & 7,8 & 1,56 & 20,03 & 7,4 & 35208 & 0,61 \\
\hline & $10<\mathrm{ha} \leq 20$ & 18118 & 14,2 & 1,93 & 13,61 & 15,0 & 32111 & 0,68 \\
\hline & $20<\mathrm{ha} \leq 30$ & 21240 & 25,1 & 1,69 & 6,74 & 2,5 & 25003 & 0,53 \\
\hline & $30<$ ha $\leq 50$ & 31563 & 39,1 & 1,88 & 4,80 & 9,6 & 23127 & 0,57 \\
\hline & ha $>50$ & 56096 & 111,0 & 1,82 & 1,64 & 8,4 & 11863 & 0,50 \\
\hline \multirow{6}{*}{2011} & Średnio & 22731 & 29,1 & 1,78 & 6,12 & 11,0 & 21813 & 0,60 \\
\hline & $5<\mathrm{ha} \leq 10$ & 11496 & 7,7 & 1,70 & 22,03 & 13,4 & 39665 & 0,61 \\
\hline & $10<\mathrm{ha} \leq 20$ & 17008 & 14,4 & 1,88 & 13,05 & 13,8 & 32976 & 0,68 \\
\hline & $20<\mathrm{ha} \leq 30$ & 20513 & 25,4 & 1,66 & 6,53 & 4,2 & 25116 & 0,49 \\
\hline & $30<\mathrm{ha} \leq 50$ & 30532 & 39,3 & 1,90 & 4,84 & 11,2 & 24169 & 0,57 \\
\hline & ha $>50$ & 56183 & 108,1 & 1,76 & 1,63 & 7,4 & 12876 & 0,50 \\
\hline \multirow{6}{*}{2012} & Średnio & 22375 & 29,0 & 1,78 & 6,12 & 12,0 & 22321 & 0,60 \\
\hline & $5<\mathrm{ha} \leq 10$ & 11140 & 7,7 & 1,57 & 20,24 & 8,2 & 38682 & 0,60 \\
\hline & $10<\mathrm{ha} \leq 20$ & 16892 & 14,3 & 1,82 & 12,74 & 12,1 & 34167 & 0,68 \\
\hline & $20<\mathrm{ha} \leq 30$ & 19831 & 25,1 & 1,71 & 6,81 & 7,9 & 24765 & 0,52 \\
\hline & $30<$ ha $\leq 50$ & 29920 & 39,6 & 1,97 & 4,97 & 14,1 & 24520 & 0,56 \\
\hline & ha $>50$ & 57970 & 113,8 & 1,81 & 1,59 & 10,0 & 13222 & 0,50 \\
\hline \multirow{6}{*}{2013} & Średnio & 22225 & 29,5 & 1,75 & 5,95 & 11,9 & 22492 & 0,61 \\
\hline & $5<\mathrm{ha} \leq 10$ & 10524 & 7,8 & 1,59 & 20,38 & 9,9 & 39231 & 0,60 \\
\hline & $10<\mathrm{ha} \leq 20$ & 17040 & 14,1 & 1,81 & 12,82 & 11,8 & 33517 & 0,67 \\
\hline & $20<\mathrm{ha} \leq 30$ & 19988 & 24,9 & 1,72 & 6,90 & 7,4 & 26615 & 0,57 \\
\hline & $30<\mathrm{ha} \leq 50$ & 28682 & 39,7 & 1,90 & 4,77 & 15,4 & 24819 & 0,57 \\
\hline & ha $>50$ & 57977 & 114,6 & 1,76 & 1,54 & 10,0 & 13720 & 0,50 \\
\hline
\end{tabular}

${ }^{a}$ Według metodyki FADN nakłady pracy stanowią całkowity nakład pracy w ramach działalności operacyjnej gospodarstwa rolnego i wyrażone są w osobach pełnozatrudnionych AWU (ang. Annual Work Unit). Do roku 2010 jednostce AWU odpowiadało 2200 godzin pracy, a od roku 2011 jest to równowartość 2120 godzin.

Źródło: Obliczenia własne na podstawie danych Polskiego FADN. 
W ciągu czterech lat w zasobach czynników produkcji zaszły pewne, choć niezbyt duże zmiany (tabela 2). Zarówno średnio w całej zbiorowości, jak i w poszczególnych grupach obszarowych gospodarstw odnotowano spadek wielkości ekonomicznej. Wyjątkiem pod tym względem były gospodarstwa największe obszarowo. W roku 2013 w porównaniu z rokiem 2010 ich siła ekonomiczna wzrosła o 3,4\%, najbardziej też zwiększyła się powierzchnia ziemi i wartość aktywów na 1 ha UR; jednocześnie zaznaczył się największy spadek zasobów pracy ogółem. Co istotne, poza grupą tych największych gospodarstw, we wszystkich pozostałych grupach miał miejsce spadek zasobów własnej siły roboczej w roku 2013 w stosunku do roku 2010. Może to sygnalizować zachodzące zmiany na rynku pracy w rolnictwie i weryfikować poglądy o dużych zasobach pracy w rolnictwie, sprzyjających rozwojowi rolnictwa ekologicznego.

Tabela 2

Dynamika zmian wartości czynników produkcji i wielkości ekonomicznej w roku 2013 $w$ relacji do $2010(2010=100)$

\begin{tabular}{cccccc}
\hline $\begin{array}{c}\text { Grupy } \\
\text { gospodarstw }\end{array}$ & $\begin{array}{c}\text { Wielkość } \\
\text { ekonomiczna } \\
\text { (euro) }\end{array}$ & $\begin{array}{c}\text { Powierzchnia } \\
\text { UR } \\
\text { (ha) }\end{array}$ & $\begin{array}{c}\text { Zasoby } \\
\text { pracy } \\
\text { ogółem } \\
\text { (AWU) }\end{array}$ & $\begin{array}{c}\text { Zasoby } \\
\text { pracy własnej } \\
\text { (FWU) }\end{array}$ & $\begin{array}{c}\text { Wartość } \\
\text { aktywów } \\
\text { na 1 ha UR } \\
\text { (zł) }\end{array}$ \\
\hline Średnio & $\mathbf{9 6 , 2}$ & $\mathbf{1 0 3 , 1}$ & $\mathbf{9 8 , 4}$ & $\mathbf{9 6 , 4}$ & $\mathbf{1 0 7 , 0}$ \\
$5<\mathrm{ha} \leq 10$ & 91,2 & 100,1 & 101,9 & 99,1 & 111,4 \\
$10<$ ha $\leq 20$ & 94,1 & 99,2 & 93,5 & 96,9 & 104,4 \\
$20<$ ha $\leq 30$ & 94,1 & 99,3 & 101,7 & 96,6 & 106,4 \\
$30<$ ha $\leq 50$ & 90,9 & 101,5 & 100,9 & 94,5 & 107,3 \\
ha $>50$ & 103,4 & 103,2 & 96,5 & 100,1 & 115,6
\end{tabular}

Źródło: Obliczenia własne na podstawie danych Polskiego FADN.

O możliwościach produkcyjnych gospodarstwa decydują nie tylko zasoby ziemi, ale jej jakość. Jak podano w tabeli 1, wskaźnik bonitacji średnio dla całej zbiorowości gospodarstw wynosił zaledwie 0,60. Jego przeciętna wartość w poszczególnych grupach obszarowych najwyższa była w gospodarstwach posiadających od 10 do 20 ha ziemi $(0,68-0,67)$, a najniższa w największych obszarowo $(0,50)$. Oznacza to, że możliwości produkcyjne tych gospodarstw są ograniczone, bo są to gleby słabe ${ }^{9}$. Wydaje się, że tak niska jakość gleb w analizowanych gospodarstwach sygnalizuje pewien symptom, mianowicie, rezygnowanie z konwencjonalnych metod wytwarzania na korzyść ekologicznych w przypadku słabych gleb.

\footnotetext{
${ }^{9}$ Na podstawie wskaźnika bonitacji gleb w Polsce wyróżnia się cztery przedziały klasowe gleb, w których gleby najsłabsze jakościowo, opisane jako gleby słabe, mają wskaźnik do 0,80 . Następny przedział od 0,81 do 1,20 oznacza gleby średnie. Gleby najwyższej jakości posiadają wartość wskaźnika powyżej 1,60 (Harasim, 2006).
} 
Organizacja produkcji. Bez wątpienia niska jakość gleb wpłynęła na strukturę upraw, a zarazem na stan pogłowia zwierząt.

Srednio w całej zbiorowości przeważały w użytkach rolnych uprawy pastewne (50-54\%). Ich udział zwiększał się nieznacznie w kolejnych latach - wzrastał wraz ze wzrostem powierzchni gospodarstwa, przy czym największy był w obiektach „średnio-dużych” (od 61 do 64\% UR) (tabela 3). Co istotne, w znacznej części tych gospodarstw w uprawach pastewnych przeważały użytki zielone.

Powszechnie uprawiano też zboża. Średnio w całej zbiorowości ich udział w UR był malejący - od 37\% w 2010 roku do 33\% w 2013 roku. Na ich uprawie skoncentrowały się przede wszystkim gospodarstwa największe ( $>50$ ha) i najmniejsze obszarowo (5-10 ha) - zboża zajmowały od 36 do 40\% powierzchni UR. Wyjątkiem był rok 2010, kiedy gospodarstwa „bardzo duże” miały prawie $45 \%$ UR obsianych zbożami (tabela 3 ). Tak popularne nie były już sady owocowe i warzywa. Plantacje te występowały głównie w strukturze UR gospodarstw mniejszych obszarowo. W latach 2010-2013 w jednostkach ,małych" powierzchnia sadów wynosiła średnio około 1 ha (12-14\% obszaru UR), a w ,średnio-małych" w przybliżeniu 0,7 ha (około 5\% UR). Największy obszar uprawy warzyw był w gospodarstwach ,średnio-małych" i wahał się w ciągu lat od 0,6 do 0,8 ha (około 4-5\% w UR). Zwłaszcza w gospodarstwach „,dużych” (30-50 ha) znaczną rolę pełniły uprawy pozostałe ${ }^{10}$, z udziałem około 13-14\%; $\mathrm{w}$ innych grupach ich udział kształtował się zmiennie od 7 do $11 \%$.

Uprawa roślin pastewnych we wszystkich grupach gospodarstw wiązała się $\mathrm{z}$ chowem zwierząt trawożernych. Średnio w całej zbiorowości na 1 sztukę LU ${ }^{11}$, prowadzoną systemem wypasowym przypadało 1,9 do 2,1 ha powierzchni paszowej - tabela 4. W dwóch najmniejszych obszarowo grupach (od 5 do 20 ha) uprawa roślin pastewnych zajmowała tylko od 0,7 do 1,2 ha. W miarę wzrostu powierzchni gospodarstwa następowało również zwiększenie powierzchni paszowej, która w jednostkach „bardzo dużych” wynosiła aż od 5,7 do 6,4 ha na 1 sztukę zwierzęcia trawożernego.

Pogłowie zwierząt $w$ analizowanych gospodarstwach wykazywało tendencję spadkową i średnio w całej zbiorowości kształtowało się w granicach od 10,42 do 9,71 LU w kolejnych latach. Należy zauważyć, że tak ważne z punktu widzenia rynku żywności ekologicznej pogłowie krów mlecznych wynosiło średnio 1-3 szt. na gospodarstwo, przy czym corocznie ich nieco ubywało - tabela $4^{12}$.

\footnotetext{
${ }^{10}$ Uprawy pozostałe obejmują pozostałe uprawy polowe (oznaczone symbolem SE041 w metodyce FADN) oraz odłogi i ugory.

${ }^{11}$ LU - jednostka przeliczeniowa zwierząt (ang. Livestock Unit). Jedna jednostka przeliczeniowa LU jest równoważna 1 krowie mlecznej albo 1 bykowi w wieku 2 lub więcej lat. Pozostałe zwierzęta stanowią odpowiednio część takiej jednostki przeliczeniowej, np. tucznik $=0,3 \mathrm{LU}$, owce $=0,1 \mathrm{LU}$, kury nioski $=0,014 \mathrm{LU}$.

${ }^{12}$ Tendencja ta jest odwzorowaniem sytuacji w pogłowiu ekologicznych krów mlecznych w Polsce. Według IJHAR-S, w roku 2013 ubyło około 20\% krów w porównaniu do roku 2010, w którym było ich niespełna 24 tys. sztuk. W zamian rolnicy wprowadzają bydło opasowe, które w roku 2010 liczyło 16,7 tys. sztuk, a w roku 2013 prawie 20 tys. sztuk (przyrost o około 19\%) - niepublikowane dane IJHAR-S.
} 
Tendencja malejąca w latach, choć niewielka, widoczna jest także w obsadzie zwierząt na 1 ha UR, zarówno w całej zbiorowości, jak i w poszczególnych grupach. Wyjątkiem były gospodarstwa „,bardzo duże”, w których obsada ta w roku 2010 wynosiła tylko 0,11 LU i w kolejnych latach nieco się zwiększyła. Niskie pogłowie zwierząt w gospodarstwach większych obszarowo mogło być spowodowane brakiem siły roboczej, potrzebnej do obsługi stada. Jak wskazano w tabeli 1, zasoby pracy w gospodarstwach „małych” i ,średnio-małych” były nawet kilkukrotnie większe niż w pozostałych grupach gospodarstw.

Tabela 3

Powierzchnia i struktura upraw gospodarstw ekologicznych w latach 2010-2013

\begin{tabular}{|c|c|c|c|c|c|c|c|c|c|c|c|}
\hline \multirow[b]{2}{*}{ Lata } & \multirow[b]{2}{*}{$\begin{array}{l}\text { Grupy } \\
\text { gospo- } \\
\text { darstw }\end{array}$} & \multicolumn{5}{|c|}{ Powierzchnia upraw (ha) } & \multicolumn{5}{|c|}{ Struktura upraw (\%) } \\
\hline & & Zboża & Sady & $\begin{array}{l}\text { Wa- } \\
\text { rzy- } \\
\text { wa }\end{array}$ & $\begin{array}{c}\text { Uprawy } \\
\text { pastew- } \\
\text { ne }\end{array}$ & $\begin{array}{l}\text { Pozos- } \\
\text { tałe } \\
\text { upra- } \\
\text { wy }\end{array}$ & Zboża & Sady & $\begin{array}{l}\text { Wa- } \\
\text { rzy- } \\
\text { wa }\end{array}$ & $\begin{array}{c}\text { Uprawy } \\
\text { pastew- } \\
\text { ne }\end{array}$ & $\begin{array}{l}\text { Pozos- } \\
\text { tałe } \\
\text { upra- } \\
\text { wy }\end{array}$ \\
\hline \multirow{6}{*}{2010} & Średnio & 10,6 & 0,7 & 0,4 & 14,2 & 2,7 & 37,0 & 2,4 & 1,3 & 49,8 & 9,5 \\
\hline & $5<\mathrm{ha}<10$ & 2,8 & 1,0 & 0,2 & 2,9 & 0,9 & 36,3 & 12,4 & 2,4 & 37,8 & 11,2 \\
\hline & $10<$ ha $<20$ & 4,7 & 0,7 & 0,8 & 6,4 & 1,6 & 33,3 & 5,0 & 5,4 & 45,1 & 11,2 \\
\hline & $20<$ ha $<30$ & 6,8 & 0,7 & 0,2 & 15,2 & 2,2 & 26,9 & 2,9 & 0,7 & 60,8 & 8,7 \\
\hline & $30<$ ha $<50$ & 12,5 & 0,0 & 0,4 & 21,1 & 5,1 & 32,0 & 0,1 & 1,0 & 53,8 & 13,1 \\
\hline & ha $>50$ & 49,7 & 0,4 & 0,0 & 52,8 & 8,0 & 44,8 & 0,4 & 0,0 & 47,6 & 7,2 \\
\hline \multirow{6}{*}{2011} & Średnio & 10,0 & $\mathbf{0 , 7}$ & 0,4 & 15,2 & 2,7 & 34,4 & 2,4 & 1,3 & 52,5 & 9,4 \\
\hline & $5<\mathrm{ha}<10$ & 2,9 & 1,1 & 0,2 & 2,7 & 0,8 & 37,9 & 13,8 & 2,8 & 35,0 & 10,6 \\
\hline & $10<$ ha $<20$ & 4,9 & 0,6 & 0,7 & 6,9 & 1,2 & 34,2 & 4,5 & 4,7 & 48,3 & 8,3 \\
\hline & $20<\mathrm{ha}<30$ & 6,0 & 0,8 & 0,2 & 16,3 & 2,1 & 23,7 & 3,3 & 0,7 & 64,0 & 8,3 \\
\hline & $30<\mathrm{ha}<50$ & 11,6 & 0,1 & 0,5 & 22,8 & 4,2 & 29,6 & 0,3 & 1,3 & 58,1 & 10,6 \\
\hline & ha $>50$ & 42,9 & 0,4 & 0,1 & 54,4 & 10,3 & 39,7 & 0,4 & 0,1 & 50,4 & 9,5 \\
\hline \multirow{6}{*}{2012} & Średnio & 9,7 & 0,7 & 0,4 & 15,3 & 3,0 & 33,3 & 2,4 & 1,3 & 52,6 & 10,4 \\
\hline & $5<\mathrm{ha}<10$ & 2,9 & 1,0 & 0,2 & 2,8 & 0,8 & 37,5 & 12,8 & 2,5 & 36,8 & 10,4 \\
\hline & $10<\mathrm{ha}<20$ & 4,6 & 0,7 & 0,7 & 7,1 & 1,3 & 31,9 & 4,6 & 4,7 & 49,8 & 9,1 \\
\hline & $20<\mathrm{ha}<30$ & 6,0 & 0,8 & 0,3 & 15,4 & 2,6 & 24,0 & 3,3 & 1,1 & 61,3 & 10,2 \\
\hline & $30<$ ha $<50$ & 11,0 & 0,1 & 0,4 & 22,6 & 5,4 & 27,9 & 0,1 & 1,1 & 57,2 & 13,7 \\
\hline & ha $>50$ & 44,9 & 0,5 & 0,1 & 57,9 & 10,6 & 39,4 & 0,4 & 0,0 & 50,8 & 9,3 \\
\hline \multirow{6}{*}{2013} & Średnio & 9,8 & 0,6 & 0,4 & 15,8 & 2,8 & 33,1 & 2,2 & 1,3 & 53,7 & 9,7 \\
\hline & $5<\mathrm{ha}<10$ & 3,0 & 0,9 & 0,3 & 3,0 & 0,7 & 37,9 & 11,5 & 3,5 & 38,0 & 9,2 \\
\hline & $10<\mathrm{ha}<20$ & 4,1 & 0,7 & 0,6 & 7,5 & 1,2 & 28,8 & 4,7 & 4,3 & 53,5 & 8,7 \\
\hline & $20<\mathrm{ha}<30$ & 5,7 & 0,7 & 0,3 & 15,7 & 2,4 & 23,0 & 2,9 & 1,4 & 62,9 & 9,8 \\
\hline & $30<\mathrm{ha}<50$ & 11,7 & 0,1 & 0,5 & 22,3 & 5,2 & 29,4 & 0,1 & 1,2 & 56,1 & 13,2 \\
\hline & ha $>50$ & 45,0 & 0,2 & 0,1 & 59,7 & 9,7 & 39,3 & 0,2 & 0,1 & 52,1 & 8,4 \\
\hline
\end{tabular}

Źródło: Obliczenia własne na podstawie danych Polskiego FADN. 
Tabela 4

Pogłowie zwierzat i jego struktura procentowa $w$ gospodarstwach ekologicznych w latach 2010-2013

\begin{tabular}{|c|c|c|c|c|c|c|c|c|c|c|c|}
\hline \multirow{2}{*}{ Lata } & \multirow{2}{*}{$\begin{array}{l}\text { Grupy } \\
\text { gospo- } \\
\text { darstw }\end{array}$} & \multicolumn{2}{|c|}{$\begin{array}{c}\text { Pogłowie } \\
\text { zwierząt } \\
\text { (LU) }\end{array}$} & \multirow{2}{*}{$\begin{array}{c}\text { Powierz- } \\
\text { chnia } \\
\text { paszowa } \\
\text { na } 1 \mathrm{LU}^{\mathrm{a}}\end{array}$} & \multirow{2}{*}{$\begin{array}{c}\text { LU/ha } \\
\text { UR }\end{array}$} & \multicolumn{6}{|c|}{ Struktura pogłowia zwierząt (\%) } \\
\hline & & ogółem & $\begin{array}{c}\text { krów } \\
\text { mlecz- } \\
\text { nych }\end{array}$ & & & $\begin{array}{c}\text { Krowy } \\
\text { mlecz- } \\
\text { ne }\end{array}$ & $\begin{array}{c}\text { Bydło } \\
\text { po- } \\
\text { zos- } \\
\text { tałe }\end{array}$ & $\begin{array}{l}\text { Owce } \\
\text { i kozy }\end{array}$ & Drób & $\begin{array}{c}\text { Trzoda } \\
\text { chlew- } \\
\text { na }\end{array}$ & $\begin{array}{l}\text { Pozo- } \\
\text { stałe }\end{array}$ \\
\hline \multirow{7}{*}{2010} & Średnio & 10,42 & 2,89 & 1,9 & 0,36 & 27,7 & 38,7 & 6,6 & 8,8 & 11,6 & 6,5 \\
\hline & $5<\mathrm{ha}<10$ & 6,21 & 2,42 & 0,8 & 0,80 & 39,0 & 21,7 & 0,1 & 16,1 & 20,1 & 2,9 \\
\hline & $10<$ ha $<20$ & 8,75 & 3,66 & 0,9 & 0,62 & 41,8 & 37,2 & 2,6 & 2,8 & 11,1 & 4,5 \\
\hline & $20<$ ha $<30$ & 13,15 & 2,91 & 1,5 & 0,52 & 22,1 & 45,9 & 8,1 & 6,6 & 12,5 & 4,8 \\
\hline & $30<\mathrm{ha}<50$ & 17,19 & 2,66 & 1,9 & 0,44 & 15,5 & 39,1 & 10,7 & 14,7 & 9,8 & 10,2 \\
\hline & ha $>50$ & 12,03 & 2,22 & 5,7 & 0,11 & 18,5 & 46,7 & 11,7 & 7,0 & 6,1 & 10,0 \\
\hline & Średnio & 9,86 & 2,82 & 2,0 & 0,34 & 28,6 & 40,9 & 6,7 & 7,3 & 10,1 & 6,3 \\
\hline \multirow{5}{*}{2011} & $5<\mathrm{ha}<10$ & 5,93 & 2,43 & 0,7 & 0,77 & 40,9 & 22,2 & 0,2 & 17,2 & 17,3 & 2,1 \\
\hline & $10<\mathrm{ha}<20$ & 8,10 & 3,46 & 1,0 & 0,56 & 42,7 & 36,9 & 2,3 & 2,8 & 9,7 & 5,6 \\
\hline & $20<$ ha $<30$ & 11,96 & 2,85 & 1,6 & 0,47 & 23,8 & 51,3 & 7,8 & 4,2 & 9,5 & 3,4 \\
\hline & $30<\mathrm{ha}<50$ & 15,72 & 2,82 & 1,9 & 0,40 & 18,0 & 46,9 & 11,7 & 10,4 & 1,2 & 11,7 \\
\hline & ha $>50$ & 13,55 & 1,95 & 5,9 & 0,13 & 14,4 & 42,6 & 11,3 & 6,6 & 18,2 & 6,8 \\
\hline \multirow{6}{*}{2012} & Średnio & 9,72 & 2,68 & 2,0 & $\mathbf{0 , 3 3}$ & 27,5 & 43,2 & 6,3 & 7,4 & 9,6 & 6,0 \\
\hline & $5<$ ha $<10$ & 5,97 & 2,61 & 0,7 & 0,77 & 43,8 & 21,5 & 0,2 & 16,8 & 16,0 & 1,8 \\
\hline & $10<\mathrm{ha}<20$ & 7,73 & 3,26 & 1,1 & 0,54 & 42,2 & 38,4 & 2,2 & 2,6 & 9,1 & 5,5 \\
\hline & $20<$ ha $<30$ & 11,55 & 2,26 & 1,6 & 0,46 & 19,6 & 55,6 & 8,8 & 2,9 & 9,6 & 3,6 \\
\hline & $30<$ ha $<50$ & 15,52 & 3,35 & 1,8 & 0,39 & 21,6 & 48,8 & 8,7 & 9,2 & 0,8 & 10,9 \\
\hline & ha $>50$ & 13,84 & 1,03 & 6,4 & 0,12 & 7,5 & 45,5 & 11,9 & 10,6 & 18,9 & 5,6 \\
\hline \multirow{6}{*}{2013} & Średnio & 9,71 & 2,62 & 2,1 & 0,32 & 27,0 & 45,9 & 6,0 & 7,5 & 7,6 & 6,1 \\
\hline & $5<$ ha $<10$ & 5,47 & 2,65 & 0,7 & 0,70 & 48,5 & 24,9 & 0,1 & 7,1 & 15,8 & 3,6 \\
\hline & $10<\mathrm{ha}<20$ & 8,06 & 3,31 & 1,2 & 0,57 & 41,1 & 38,4 & 1,7 & 6,2 & 8,1 & 4,5 \\
\hline & $20<$ ha $<30$ & 11,71 & 2,41 & 1,5 & 0,47 & 20,6 & 56,4 & 10,0 & 2,7 & 6,3 & 4,1 \\
\hline & $30<$ ha $<50$ & 15,20 & 1,93 & 1,9 & 0,38 & 12,7 & 53,5 & 10,9 & 12,0 & 0,8 & 10,0 \\
\hline & ha $>50$ & 14,23 & 2,30 & 5,9 & 0,12 & 16,2 & 49,9 & 5,2 & 9,9 & 11,0 & 7,8 \\
\hline
\end{tabular}

a Dotyczy zwierząt trawożernych.

Źródło: Obliczenia własne na podstawie danych Polskiego FADN. 
Odnosząc się do na ogół niskiej obsady zwierząt czy niskiego pogłowia zwierząt prowadzonych systemem ekologicznym, warto wiedzieć, jak ogromne obciążenia administracyjne wiążą się z ich chowem, co zniechęca często rolników do ich utrzymywania (Bielski, 2009). Rolnik zobowiązany jest, między innymi, do prowadzenia rejestru zwierząt, ich leczenia, ewidencji zużytych pasz w żywieniu, zakupionych środków do produkcji oraz wytworzonych produktów roślinnych i zwierzęcych ${ }^{13}$.

Analizując organizację produkcji, warto zwrócić uwagę na strukturę pogłowia zwierząt. Biorąc pod uwagę całą zbiorowość 196 gospodarstw, zauważamy, że dominowało bydło opasowe i jego udział zwiększał się z roku na rok. W przypadku grup obszarowych przeważało ono w gospodarstwach liczących powyżej 20 ha UR; także udział owiec i kóz był tu na ogół znacznie wyższy niż w gospodarstwach do 20 ha. Z kolei, w gospodarstwach od 5 do 20 ha ziemi w każdym roku było więcej krów niż opasów, co ma zapewne związek z pracochłonnością produkcji mleka i zasobami pracy. W gospodarstwach „małych” corocznie stosunkowo duży był udział drobiu i trzody chlewnej w pogłowiu zwierząt, choć prawdopodobnie w większości służyło to samozaopatrzeniu. Zmiennie kształtował się w latach udział drobiu, trzody chlewnej w gospodarstwach dużych i bardzo dużych.

Poziom i struktura produkcji. Sposób zorganizowania produkcji w gospodarstwach ekologicznych przekłada się na jej poziom i strukturę. Średnio dla całego zbioru gospodarstw produkcja ogółem wzrastała w ciągu trzech lat od 59237 zł w roku 2010 do 70440 zł w roku 2012, by obniżyć się do poziomu 65666 zł w roku 2013. Spowodowane było to głównie spadkiem wartości produkcji w tym ostatnim roku, po systematycznym jej wzroście w trzech pierwszych latach (2010-2012) w gospodarstwach powyżej 30 ha UR. Wartość produkcji w gospodarstwach od 5 do 20 ha cechowała się zmiennością w latach, a w grupie od 20 do 30 ha utrzymywała się na podobnym poziomie w roku 2010 i 2011, a następnie wzrastała - tabela 5 .

Średnio w całym zbiorze gospodarstw przewagę w wartości produkcji ogółem miała produkcja roślinna, ale w 2013 roku jej udział zmniejszył się w porównaniu do roku 2010 o około 4 p.p. na korzyść produkcji zwierzęcej (tabela 5). Produkcja roślinna stanowiła od 54,6\% w 2010 roku do 50,8\% w 2013 roku, a zwierzęca od $41,1 \%$ do $45,3 \%$. Niewielki (około $4 \%$ ) był udział produkcji pozostałej we wszystkich latach. W poszczególnych grupach obszarowych widoczne jest zróżnicowanie udziału produkcji roślinnej i zwierzęcej, choć w grupach obszarowych od 5 do 50 ha nie były to duże rozbieżności. Udział produkcji roślinnej wynosił od 43 do $54 \%$, a zwierzęcej od 41 do $54 \%$. W podmiotach posiadających powyżej 50 ha UR miała miejsce tendencja spadkowa udziału produkcji roślinnej na korzyść zwierzęcej - z poziomu 71,6\% w roku 2010 do 61,3\% w roku 2013.

\footnotetext{
${ }^{13}$ Na mocy Rozporządzenia Komisji (WE) nr 889/2008 z dnia 5 września 2008 r. ustanawiającego szczegółowe zasady wdrażania Rozporządzenia Rady (WE) nr 834/2007 w sprawie produkcji ekologicznej i znakowania produktów ekologicznych w odniesieniu do produkcji ekologicznej, znakowania i kontroli (Dz.U. L 250 z 18.9.2008, s. 1).
} 
W wartości produkcji roślinnej gospodarstw „małych” i „średnio-małych” (do 20 ha) największy udział miały owoce i warzywa - od 21 do $32 \%$ wartości produkcji ogółem, zmiennie w poszczególnych latach. Z kolei w gospodarstwach powyżej 20 ha UR przeważały zboża. Ich udział zdecydowanie się zmniejszył we wszystkich grupach obszarowych - w jednostkach od 20 do 50 ha z około 22-23\% w 2010 do 18-16\% w roku 2013, a w gospodarstwach $>50$ ha UR z poziomu $55 \%$ do niespełna $44 \%$.

Tabela 5

Poziom i struktura produkcji w gospodarstwach ekologicznych $w$ latach 2010-2013

\begin{tabular}{|c|c|c|c|c|c|c|c|c|c|c|}
\hline \multirow{3}{*}{ Lata } & \multirow{3}{*}{$\begin{array}{l}\text { Grupy } \\
\text { gospo- } \\
\text { darstw }\end{array}$} & \multirow{3}{*}{$\begin{array}{l}\text { Wartość } \\
\text { produkcji } \\
\text { ogółem } \\
\text { (zł) }\end{array}$} & \multicolumn{8}{|c|}{ Udział w produkcji ogółem (\%) } \\
\hline & & & \multirow{2}{*}{$\begin{array}{l}\text { produkcji } \\
\text { roślinnej }\end{array}$} & \multicolumn{2}{|c|}{ w tym: } & \multirow{2}{*}{$\begin{array}{l}\text { produkcji } \\
\text { zwierzęcej }\end{array}$} & \multicolumn{3}{|c|}{ w tym: } & \multirow{2}{*}{$\begin{array}{c}\text { produ- } \\
\text { kcji } \\
\text { pozos- } \\
\text { tałej }\end{array}$} \\
\hline & & & & $z b o ́ \dot{z}$ & $\begin{array}{l}\text { owoców } \\
i \text { warzyw }\end{array}$ & & $\overline{m l e k a^{a}}$ & jaj & $\begin{array}{c}\dot{z} y w c a \\
\text { wołowego }\end{array}$ & \\
\hline \multirow{6}{*}{2010} & Średnio & 59237 & 54,6 & 25,0 & 16,5 & 41,1 & 14,9 & 4,6 & 12,0 & 4,3 \\
\hline & $5<$ ha $<10$ & 34301 & 44,5 & 15,1 & 21,2 & 52,3 & 19,2 & 11,3 & 10,5 & 3,2 \\
\hline & $10<\mathrm{ha}<20$ & 59485 & 54,2 & 13,7 & 27,5 & 40,6 & 21,8 & 0,9 & 10,5 & 5,1 \\
\hline & $20<\mathrm{ha}<30$ & 48871 & 43,4 & 22,4 & 8,7 & 53,7 & 13,8 & 5,8 & 20,7 & 3,0 \\
\hline & $30<\mathrm{ha}<50$ & 71657 & 49,0 & 22,7 & 11,0 & 47,0 & 9,8 & 5,3 & 14,5 & 4,0 \\
\hline & ha $>50$ & 111827 & 71,6 & 55,2 & 1,0 & 23,2 & 7,1 & 5,1 & 8,0 & 5,2 \\
\hline \multirow{6}{*}{2011} & Średnio & 65262 & 55,5 & 24,4 & 16,2 & 40,7 & 14,6 & 4,1 & 12,5 & 3,8 \\
\hline & $5<\mathrm{ha}<10$ & 42257 & 54,1 & 12,2 & 32,0 & 41,9 & 16,8 & 7,6 & 8,5 & 4,0 \\
\hline & $10<\mathrm{ha}<20$ & 62132 & 53,1 & 15,0 & 24,5 & 42,0 & 20,9 & 1,0 & 11,0 & 4,9 \\
\hline & $20<\mathrm{ha}<30$ & 48821 & 47,9 & 22,0 & 7,9 & 50,5 & 17,3 & 2,8 & 20,3 & 1,6 \\
\hline & $30<\mathrm{ha}<50$ & 80297 & 49,6 & 20,6 & 12,2 & 46,5 & 11,5 & 2,5 & 18,5 & 3,9 \\
\hline & ha $>50$ & 127161 & 67,6 & 50,3 & 0,8 & 29,1 & 5,3 & 8,4 & 8,7 & 3,2 \\
\hline \multirow{6}{*}{2012} & Średnio & 70444 & 54,3 & 24,0 & 14,9 & 42,1 & 14,0 & 4,5 & 14,3 & 3,6 \\
\hline & $5<\mathrm{ha}<10$ & 37026 & 45,3 & 14,1 & 24,1 & 51,0 & 24,1 & 6,2 & 11,6 & 3,7 \\
\hline & $10<\mathrm{ha}<20$ & 62788 & 50,2 & 16,0 & 21,3 & 44,9 & 21,8 & 1,2 & 12,8 & 4,9 \\
\hline & $20<\mathrm{ha}<30$ & 51109 & 47,9 & 22,5 & 10,9 & 49,9 & 12,5 & 2,8 & 24,7 & 2,2 \\
\hline & $30<\mathrm{ha}<50$ & 90393 & 49,2 & 20,2 & 11,7 & 47,5 & 11,7 & 2,9 & 21,0 & 3,3 \\
\hline & ha $>50$ & 162281 & 67,0 & 43,7 & 0,7 & 29,8 & 3,2 & 10,1 & 8,1 & 3,3 \\
\hline \multirow{6}{*}{2013} & Średnio & 65666 & 50,8 & 20,6 & 16,9 & 45,3 & 16,7 & 5,0 & 14,5 & 3,9 \\
\hline & $5<$ ha $<10$ & 40860 & 46,6 & 10,8 & 28,8 & 49,7 & 26,6 & 2,2 & 12,8 & 3,7 \\
\hline & $10<$ ha $<20$ & 59636 & 45,9 & 11,5 & 22,4 & 49,1 & 26,0 & 2,7 & 10,6 & 5,1 \\
\hline & $20<\mathrm{ha}<30$ & 55464 & 49,0 & 18,4 & 16,9 & 48,8 & 14,8 & 2,7 & 23,4 & 2,1 \\
\hline & $30<\mathrm{ha}<50$ & 76538 & 45,4 & 16,4 & 12,2 & 50,2 & 9,1 & 3,8 & 20,6 & 4,4 \\
\hline & ha $>50$ & 135585 & 61,3 & 43,6 & 0,9 & 35,1 & 6,9 & 12,4 & 11,2 & 3,6 \\
\hline
\end{tabular}

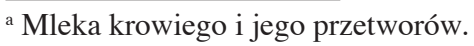

Źródło: Obliczenia własne na podstawie danych Polskiego FADN. 
W produkcji zwierzęcej w gospodarstwach do 20 ha dominowała produkcja mleka krowiego i jego przetworów, a w gospodarstwach od 20 do 50 ha produkcja żywca wołowego. W gospodarstwach do 20 ha UR udział mleka i przetworów wynosił od 17 do prawie $27 \%$ wartości produkcji ogółem w poszczególnych latach, z tendencją rosnącą, z wyjątkiem roku 2011. Pamiętając jednak o niskim pogłowiu krów mlecznych, ranga tej produkcji w rynku żywności ekologicznej była prawdopodobnie niewielka. We wszystkich grupach gospodarstw obserwowano wzrost udziału produkcji żywca wołowego. W gospodarstwach „małych” w granicach od 9 do $13 \%$ wartości produkcji ogółem w kolejnych latach, czyli około 2-krotnie mniej niż w gospodarstwach posiadających od 20 do 50 ha, zajmujących czołową pozycję pod względem udziału w produkcji ogółem. W gospodarstwach posiadających więcej niż 50 ha UR w strukturze produkcji zwierzęcej znaczący był udział żywca wołowego i jaj. Zwłaszcza produkcja jaj w tych gospodarstwach zwiększała się z roku na rok, przewyższając w roku 2012 i 2013 udział produkcji wołowiny, co wskazuje na rosnącą koniunkturę na rynku na te produkty.

Koszty $\boldsymbol{i}$ ich efektywność. Poziom produkcji uzależniony jest w dużym stopniu od poniesionych nakładów środków produkcji, które w ujęciu wartościowym wyrażają intensywność produkcji. W analizowanych gospodarstwach koszty na 1 ha UR kształtowały się średnio dla całej zbiorowości od 1826 zł w 2010 roku do 2189 zł w 2013 roku i z roku na rok rosły (tabela 6). Najwyższe były w gospodarstwach najmniejszych obszarowo i wynosiły od około 3700 do 4500 zł. Ze wzrostem obszaru gospodarstw intensywność produkcji malała, zniżając się do wartości zaledwie około 1000-1300 zł w gospodarstwach „,bardzo dużych". Wskazuje to na ekstensyfikację produkcji w tych podmiotach. Nieprzypadkowo zatem osiągano tu bardzo niską produktywność ziemi, która mierzona wartością produkcji na 1 ha kształtowała się też w podobnych granicach jak koszty (1000-1400 zł/ha). W pozostałych grupach obszarowych gospodarstw poziom produkcji był zróżnicowany w latach, ale największe rozbieżności występowały w gospodarstwach „małych”, uzyskujących najwyższą produktywność ziemi. W roku 2010 wartość produkcji na 1 ha UR wynosiła 4396 zł, a w kolejnych latach 5484 zł, 4787 zł i 5232 zł. Poziom tego wskaźnika był bardziej wyrównany w gospodarstwach ,średnio-małych” (10-20 ha) - wahał się w przedziale 4200-4400 zł/ha na przestrzeni lat. W stosunku do tych gospodarstw w jednostkach „średnio-dużych” i „dużych” (20-50 ha) wartość produkcji na 1 ha UR była około połowę niższa, a w „bardzo dużych” (>50 ha) niższa nawet 3-4 razy. Należy zauważyć, że w tych „,bardzo dużych” gospodarstwach osiągano produkcję poniżej wartości pozyskiwanych dopłat do działalności operacyjnej - tabela 6.

Przedstawione wyniki potwierdzają pogląd, że w rolnictwie ekologicznym efektywność ziemi maleje ze wzrostem powierzchni UR. Osiągane wyniki produktywności ziemi pokazują, jak ważna jest w rolnictwie ekologicznym właści- 
wa obsada zwierząt na hektar, dostarczających naturalnych nawozów. Jak podano w tabeli 1, wszystkie grupy gospodarstw dysponowały podobną, niską jakością gleb, a pomimo to gospodarstwa najmniejsze obszarowo z najwyższą obsadą zwierząt osiągały dość wysoką produkcję.

Analiza wyników w okresie 4-letnim wskazuje na niekorzystne relacje pod względem dynamiki wzrostu kosztów i produkcji. Na podstawie danych tabeli 6 wyliczono, że średnio dla całego zbioru gospodarstw produkcja na 1 ha UR wzrosła w roku 2013 o 7,7\% w stosunku do roku 2010, a koszty ogółem o $19,9 \%$. W tym czasie kwota dopłat do działalności operacyjnej na 1 ha UR zwiększyła się średnio o 12,2\%. Podobnie niekorzystnie kształtowały się relacje pomiędzy dynamiką wzrostu produkcji i kosztów we wszystkich grupach gospodarstw. W tym okresie badawczym wzrost kosztów był wyższy od wzrostu wartości produkcji.

Odwrotnie niż produktywność ziemi kształtowała się ekonomiczna wydajność pracy (tabela 6), która wzrastała w miarę zwiększania obszaru gospodarstw, za wyjątkiem grupy od 20 do 30 ha UR. W gospodarstwach „,bardzo dużych" wartość tego wskaźnika wyróżniała się na tle pozostałych grup. Produkcja na 1 AWU rosła od 61379 zł w 2010 roku do 89682 zł w 2012 roku, po czym spadła do 77037 zł w 2013 roku. Były to wartości nawet 3-4-krotnie wyższe niż w gospodarstwach najmniejszych obszarowo, głównie z powodu dużo niższych zasobów pracy. Pod względem efektywności wykorzystania aktywów, podobnie jak w przypadku ziemi, lepsze były gospodarstwa do 20 ha UR; produkcja na 100 zł aktywów wynosiła około 12-13 zł, a w gospodarstwach powyżej 20 ha UR na ogół była w granicach 8 do 11 zł.

Relacje zachodzące między poziomem kosztów a poziomem uzyskanej produkcji stanowią o trwałości gospodarstwa, możliwościach rozwoju. W okresie czterech lat prowadzenia działalności rolniczej tylko w roku 2010 we wszystkich grupach gospodarstw produkcja była opłacalna, biorąc pod uwagę nadwyżkę produkcji na hektar po odjęciu kosztów (tabela 6). W roku 2013 poniesiono stratę z produkcji we wszystkich gospodarstwach większych od 20 ha UR; w 2011 i 2012 roku te gospodarstwa były również dotknięte stratą albo uzyskały bardzo niską nadwyżkę. Kwoty nadwyżki rzędu 14 czy 105 zł miały raczej wymiar symboliczny. Z analizy danych wynika, że praktycznie z tytułu samej działalności produkcyjnej badane gospodarstwa większe od 20 ha UR nie miały możliwości przetrwania. Ich funkcjonowanie zapewniały dopłaty.

Ocena efektywności gospodarowania. Podstawową kategorią dochodową w metodyce FADN jest dochód z rodzinnego gospodarstwa rolnego (DzRGR). Ta nadwyżka ekonomiczna stanowi opłatę za poniesione $\mathrm{w}$ działalności produkcyjnej nakłady własnych czynników wytwórczych (ziemi, pracy, kapitału) i za zarządzanie gospodarstwem. Pożądane jest, by była ona jak najwyższa, gdyż jej poziom, a także inwestycje decydują o zdolnościach rozwojowych gospodarstwa (Józwiak, 2014). Jak wykazano w tabeli 7, włączenie dopłat do rachun- 
ku dochodu poprawiło znacząco sytuację ekonomiczną analizowanych gospodarstw i umożliwiało ich funkcjonowanie. Można to stwierdzenie odnieść w zasadzie do gospodarstw wszystkich grup obszarowych.

Tabela 6

Koszty ogółem i produktywność środków produkcji w gospodarstwach ekologicznych w latach 2010-2013

\begin{tabular}{|c|c|c|c|c|c|c|c|}
\hline \multirow[t]{2}{*}{ Lata } & \multirow[t]{2}{*}{$\begin{array}{c}\text { Grupy } \\
\text { gospodarstw }\end{array}$} & $\begin{array}{l}\text { Produkcja } \\
\text { ogółem }\end{array}$ & $\begin{array}{l}\text { Koszty } \\
\text { ogółem }\end{array}$ & $\begin{array}{c}\text { Nadwyżka } \\
\text { produkcji } \\
\text { nad } \\
\text { kosztami }\end{array}$ & Dopłaty & \multirow[t]{2}{*}{$\begin{array}{c}\text { Produkcja } \\
\text { na AWU } \\
\text { (zł) }\end{array}$} & \multirow[t]{2}{*}{$\begin{array}{l}\text { Produkcja } \\
\text { na } 100 \text { zł } \\
\text { aktywów } \\
\text { (zł) }\end{array}$} \\
\hline & & \multicolumn{4}{|c|}{ w zł/ha } & & \\
\hline \multirow{6}{*}{2010} & Średnio & 2070 & 1826 & 245 & 1640 & 33226 & 9,9 \\
\hline & $5<\mathrm{ha}<10$ & 4396 & 3728 & 668 & 2041 & 21955 & 12,5 \\
\hline & $10<\mathrm{ha}<20$ & 4186 & 3162 & 1024 & 1769 & 30765 & 13,0 \\
\hline & $20<$ ha $<30$ & 1950 & 1845 & 105 & 1613 & 28928 & 7,8 \\
\hline & $30<$ ha $<50$ & 1831 & 1776 & 55 & 1712 & 38149 & 7,9 \\
\hline & ha $>50$ & 1007 & 994 & 13 & 1499 & 61379 & 8,5 \\
\hline \multirow{6}{*}{2011} & Średnio & 2246 & 2045 & 201 & 1822 & 36699 & 10,3 \\
\hline & $5<\mathrm{ha}<10$ & 5484 & 4468 & 1016 & 2346 & 24894 & 13,8 \\
\hline & $10<\mathrm{ha}<20$ & 4323 & 3411 & 912 & 1973 & 33132 & 13,1 \\
\hline & $20<\mathrm{ha}<30$ & 1920 & 1990 & -70 & 1929 & 29422 & 7,6 \\
\hline & $30<$ ha $<50$ & 2043 & 2029 & 14 & 1892 & 42174 & 8,5 \\
\hline & ha $>50$ & 1176 & 1203 & -27 & 1625 & 72358 & 9,1 \\
\hline \multirow{6}{*}{2012} & Średnio & 2425 & 2173 & 253 & 1759 & 39615 & 10,9 \\
\hline & $5<\mathrm{ha}<10$ & 4787 & 4254 & 533 & 1998 & 23650 & 12,4 \\
\hline & $10<$ ha $<20$ & 4394 & 3489 & 904 & 1986 & 34484 & 12,9 \\
\hline & $20<\mathrm{ha}<30$ & 2037 & 2071 & -34 & 1632 & 29894 & 8,2 \\
\hline & $30<\mathrm{ha}<50$ & 2285 & 2210 & 75 & 1898 & 45970 & 9,3 \\
\hline & ha $>50$ & 1426 & 1320 & 105 & 1610 & 89682 & 10,8 \\
\hline \multirow{6}{*}{2013} & Średnio & 2229 & 2189 & 40 & 1840 & 37505 & 9,9 \\
\hline & $5<\mathrm{ha}<10$ & 5232 & 4495 & 737 & 2127 & 25668 & 13,3 \\
\hline & $10<\mathrm{ha}<20$ & 4229 & 3600 & 629 & 1948 & 32994 & 12,6 \\
\hline & $20<\mathrm{ha}<30$ & 2228 & 2272 & -44 & 2007 & 32289 & 8,4 \\
\hline & $30<\mathrm{ha}<50$ & 1926 & 2062 & -136 & 1859 & 40367 & 7,8 \\
\hline & ha $>50$ & 1183 & 1355 & -172 & 1694 & 77037 & 8,6 \\
\hline
\end{tabular}

Źródło: Obliczenia własne na podstawie danych Polskiego FADN. 
Tabela 7

Efektywność gospodarowania, poziom inwestycji i zadłużenia $w$ gospodarstwach ekologicznych w latach 2010-2013

\begin{tabular}{|c|c|c|c|c|c|c|c|c|}
\hline \multirow[t]{2}{*}{ Lata } & \multirow[t]{2}{*}{$\begin{array}{l}\text { Grupy } \\
\text { gospo- } \\
\text { darstw }\end{array}$} & DzRGR $^{a}$ & $\begin{array}{c}\text { DzRGR } \\
\text { na } \\
\text { FWU }\end{array}$ & $\begin{array}{c}\text { Zysk } \\
\text { gospo- } \\
\text { darstwa }^{b}\end{array}$ & \multirow{2}{*}{$\begin{array}{c}\text { Udział } \\
\text { dopłat } \\
\text { w DzRGR } \\
(\%)\end{array}$} & $\begin{array}{c}\text { Inwestycje } \\
\text { brutto }\end{array}$ & $\begin{array}{c}\text { Inwestycje } \\
\text { netto }\end{array}$ & \multirow{2}{*}{$\begin{array}{l}\text { Wskaźnik } \\
\text { zadłużenia } \\
\text { aktywów } \\
(\%)\end{array}$} \\
\hline & & \multicolumn{3}{|c|}{ (zł) } & & \multicolumn{2}{|c|}{ (zł) } & \\
\hline \multirow{6}{*}{2010} & Średnio & 51912 & 33508 & 10631 & 90,4 & 15964 & 1533 & 5,6 \\
\hline & $5<\mathrm{ha}<10$ & 19201 & 13386 & -18224 & 82,9 & 6752 & -1029 & 1,0 \\
\hline & $10<\mathrm{ha}<20$ & 38884 & 23915 & -3648 & 64,6 & 12647 & -7 & 3,5 \\
\hline & $20<\mathrm{ha}<30$ & 40674 & 27640 & -1915 & 99,4 & 18734 & 4518 & 5,9 \\
\hline & $30<$ ha $<50$ & 67294 & 42452 & 23385 & 99,6 & 25104 & 6770 & 6,5 \\
\hline & ha> $>50$ & 162034 & 103412 & 118890 & 102,7 & 30591 & 731 & 8,8 \\
\hline \multirow{6}{*}{2011} & Średnio & 57714 & 38170 & 14645 & 91,8 & 23166 & 7594 & 5,9 \\
\hline & $5<\mathrm{ha}<10$ & 25293 & 18773 & -14737 & 71,5 & 11833 & 3176 & 3,4 \\
\hline & $10<$ ha $<20$ & 41094 & 26229 & -2918 & 69,0 & 10142 & -3090 & 3,1 \\
\hline & $20<\mathrm{ha}<30$ & 45084 & 32219 & 1784 & 108,8 & 10208 & -4860 & 3,9 \\
\hline & $30<$ ha $<50$ & 72891 & 45424 & 26848 & 102,0 & 29495 & 9238 & 6,1 \\
\hline & ha $>50$ & 171302 & 110740 & 126981 & 102,5 & 95647 & 63870 & 10,6 \\
\hline \multirow{6}{*}{2012} & Średnio & 57073 & 37629 & 11928 & 89,5 & 20402 & 4239 & 5,9 \\
\hline & $5<$ ha $<10$ & 18991 & 13643 & -22485 & 81,4 & 1866 & -6906 & 1,3 \\
\hline & $10<$ ha $<20$ & 39803 & 25113 & -6390 & 71,3 & 18361 & 5475 & 3,0 \\
\hline & $20<$ ha $<30$ & 37921 & 26163 & -7537 & 108,0 & 5473 & -10423 & 4,7 \\
\hline & $30<$ ha $<50$ & 76238 & 47751 & 27504 & 98,5 & 30656 & 8789 & 6,3 \\
\hline & ha $>50$ & 194281 & 128675 & 147290 & 94,4 & 75872 & 40800 & 11,3 \\
\hline \multirow{6}{*}{2013} & Średnio & 54553 & 38345 & 8597 & 99,4 & 22117 & 4524 & 6,1 \\
\hline & $5<\mathrm{ha}<10$ & 22116 & 15925 & -20606 & 75,1 & 7022 & -2709 & 1,8 \\
\hline & $10<\mathrm{ha}<20$ & 36150 & 23821 & -11347 & 76,0 & 8188 & -5514 & 3,0 \\
\hline & $20<\mathrm{ha}<30$ & 46623 & 37671 & -789 & 107,2 & 24065 & 7456 & 4,9 \\
\hline & $30<$ ha $<50$ & 66827 & 43026 & 19022 & 110,5 & 18642 & -4065 & 7,0 \\
\hline & ha $>50$ & 173642 & 119855 & 126439 & 111,8 & 94870 & 54063 & 10,6 \\
\hline \multicolumn{9}{|c|}{ Średni dochód netto w gospodarce narodowej w latach (zł) } \\
\hline \multicolumn{4}{|c|}{ Lata } & 2010 & 2011 & 2012 & 2013 & \\
\hline \multicolumn{4}{|c|}{$\mathbf{z t}$} & 25864 & 27227 & 28854 & 29798 & \\
\hline
\end{tabular}


Udział dopłat w DzRGR (dochodzie z rodzinnego gospodarstwa rolnego) był najniższy w gospodarstwach do 20 ha UR - w granicach $65-83 \%$ i zmieniał się w poszczególnych latach. W gospodarstwach posiadających więcej niż 20 ha ziemi udział dopłat w dochodzie przekroczył 100\% (od 102 do 112\%) w roku 2011 i 2013, ale w pozostałych dwóch latach oscylował również wokół 100\%, zatem dopłaty służyły także finansowaniu kosztów. Wielkość pozyskanych dopłat zależna jest od powierzchni i dlatego ze wzrostem obszaru gospodarstw ich sytuacja dochodowa poprawiała się. Gospodarstwa „małe” i ,średnio-małe", które ponosiły bardzo wysokie nakłady pracy własnej i uzyskiwały wysoką produktywność ziemi, osiągnęły jednak niską efektywność mierzoną wartością dochodu na jednostkę pracy własnej (FWU). Niskie zasoby ziemi bowiem generowały niską pulę dopłat. Można zatem stwierdzić, że większe gospodarstwa korzystały ze swego rodzaju ,premii”, bo przecież produkowały znacznie mniej niż jednostki mniejsze obszarowo.

Dochód na jednostkę pracy własnej (DzRGR/FWU) w gospodarstwach „małych" zawierał się w granicach 13-18 tys. zł, a w ,średnio-małych” 24-26 tys. zł (tabela 7). We wszystkich czterech latach badań dochód na FWU w tych dwóch grupach (od 5 do 20 ha UR) wynosił mniej niż średnie wynagrodzenie netto w gospodarce narodowej (dochód parytetowy) - tabela 7. Jednocześnie podmioty te nie wypracowały zysku z gospodarstwa, rozumianego jako różnica DzRGR i opłaty za pracę własną rolnika oraz jego rodziny - we wszystkich latach był on ujemny. W podobnej sytuacji ekonomicznej były gospodarstwa posiadające od 20 do 30 ha UR, z wyjątkiem roku 2011. Niski poziom dochodu, zwłaszcza w gospodarstwach do 20 ha, nie sprzyjał podejmowaniu działań inwestycyjnych. Na ogół nie miała tu miejsca nawet reprodukcja posiadanego majątku - inwestycje netto pozostawały na ujemnym poziomie. Gospodarstwa do 20 ha ziemi nie wykazują więc cech rozwoju, na co dodatkowo wskazuje bardzo niski poziom zadłużenia (1-3,5\% wartości aktywów). Najwidoczniej te gospodarstwa stanowiły dla swych właścicieli i rodziny wyłącznie zaplecze socjalne, źródło zatrudnienia. Przy wsparciu finansowym z zewnątrz gospodarstwa te są w stanie trwać, ewentualnie przyczyniając się do budowania lokalnego rynku produktów ekologicznych. Przy osiąganej dochodowości nie są w stanie natomiast rozwijać się i konkurować na rynku, wymagającym systematycznych dostaw towaru, a przy tym dużych partii jednorodnych surowców i gotowych produktów.

Pewne możliwości rozwoju tkwią w gospodarstwach posiadających od 20 do 30 ha UR, w których naprzemiennie w latach nie odtwarzano majątku lub inwestowano powyżej poziomu rocznej amortyzacji.

Konkurencyjne natomiast pod względem ekonomicznym i rozwojowym wobec wszystkich grup obszarowych są gospodarstwa $>50$ ha UR. Dochód na FWU przyjmował tu wartości od 103 tys. zł w roku 2010 do 129 tys. zł w 2012 roku i 120 tys. zł w 2013 roku, kilkakrotnie przekraczając poziom parytetowy w każ- 
dym roku. Zapewniło to osiągnięcie zysku z gospodarstwa w każdym roku i dokonywanie reprodukcji rozszerzonej majątku - tabela 7. Inwestycje netto, z wyjątkiem roku 2010, były na poziomie kilkuset tysięcy złotych, rolnicy zaciągali też zobowiązania finansowe na znacznie wyższym poziomie niż w gospodarstwach pozostałych. Wskaźnik zadłużenia aktywów wynosił około 9-11\%.

Szanse rozwoju tkwią także w gospodarstwach z przedziału obszarowego od 30 do 50 ha UR, za czym przemawia zarówno dodatni zysk z gospodarstwa, jak i dokonywane inwestycje netto.

\section{Podsumowanie}

W latach 2010-2013 w badanych gospodarstwach ekologicznych nastąpiły niewielkie zmiany w zakresie zasobów środków produkcji, ale - co wydaje się ważne - zarysowała się tendencja spadkowa w zasobach własnej siły roboczej w roku 2013 w stosunku do roku 2010 w gospodarstwach do 50 ha użytków rolnych. Negatywną, wspólną cechą wszystkich gospodarstw ekologicznych była bardzo niska jakość gleb, co zdecydowanie wpłynęło na wyniki produkcyjne. Wartość wskaźnika bonitacji wahała się od 0,49 do 0,68. Rodzi się pytanie, czy niska jakość gleb w gospodarstwach ekologicznych w Polsce jest ich charakterystyczną cechą.

Efekty produkcyjne wyrażone za pomocą wskaźnika produktywności były dość podobne w kolejnych latach w poszczególnych grupach gospodarstw. Jego wartość wahała się od 5,5 do 1,2 tys. zł/ha i zawsze malała ze wzrostem powierzchni UR. Gospodarstwa mniejsze obszarowo (5-20 ha UR) osiągały wyższą produktywność, włączając do upraw warzywa i rośliny sadownicze, ale też poprawiając żyzność gleby poprzez utrzymywanie zalecanej dla gospodarstw ekologicznych obsady zwierząt.

Czteroletni okres obserwacji badanych gospodarstw ekologicznych dowodzi również, że ze wzrostem powierzchni gospodarstw malała nie tylko produkcja na hektar, ale także koszty produkcji. Sugeruje to, że rolnicy większych obszarowo gospodarstw, przynajmniej niektórych, nie przywiązują wagi do poprawy intensywności produkcji, a przez to do zwiększania jej efektywności - dochód zapewniają im dopłaty. Z roku na rok wsparcie ze środków zewnętrznych stanowiło bowiem coraz większy udział w dochodzie gospodarstw, nie tylko największych, umniejszając tym samym rolę wytwarzanej produkcji.

$\mathrm{Z}$ analizy danych $\mathrm{z}$ okresu czterech lat wynika, że w obecnych warunkach trwałość na rynku zapewniają gospodarstwom prowadzącym wyłącznie produkcję metodami ekologicznymi przede wszystkim odpowiednie zasoby ziemi. Powinny one wynosić co najmniej 20-30 ha. Gospodarstwa ekologiczne do 30 ha UR, najprężniejsze $\mathrm{w}$ zakresie towarowości produkcji, nie były w stanie zrekompensować osiąganymi dochodami nawet kosztów własnej pracy. Tylko gospodarstwa powyżej 30 ha UR realizowały reprodukcję rozszerzoną majątku, osiągały zysk z gospodarstwa. Jednak trzeba pamiętać, że wysokie docho- 
dy, zwłaszcza gospodarstw o powierzchni większej niż 50 ha UR, w porównaniu do pozostałych grup gospodarstw były zasługą pozyskanych dopłat. Rozwój i konkurowanie na rynku powinno oznaczać dla nich konieczność dużych zmian w odniesieniu do zasad produkcji ekologicznej. Utrzymanie wyników produkcyjnych na poziomie uzyskiwanym w minionych 4 latach nie prognozuje wzrostu ich udziału w rozwoju rynku żywności ekologicznej. 


\section{Bibliografia:}

Bielski, P. (2009). Rolnictwo ekologiczne jako zawód i powołanie. Przegląd Socjologii Jakościowej. Monografie. T. V, nr 3, seria BECOMING.

Bocian, M., Cholewa, I., Tarasiuk, R. (2014). Wspótczynniki Standardowej Produkcji „2010” dla celów Wspólnotowej Typologii Gospodarstw Rolnych. Warszawa: IERiGŻ-PIB.

Brodzińska, K. (2014). Rolnictwo ekologiczne - tendencje i kierunki zmian. Zeszyty Naukowe Szkoły Głównej Gospodarstwa Wiejskiego w Warszawie. Problemy Rolnictwa Światowego, t. 14 (XXIX), z. 3, s. 27-36. Wydawnictwo SGGW.

Goraj, L., Mańko, S. (2011). Model szacowania pełnych kosztów działalności gospodarstw rolnych. Zagadnienia Ekonomiki Rolnej, nr 3, s. 53.

Harasim, A. (2006). Przewodnik ekonomiczno-rolniczy w zarysie. Puławy: IUNG.

Józwiak, W. (red.). (2014). Efektywność, koszty produkcji i konkurencyjność polskich gospodarstw rolnych obecnie $i w$ perspektywie średnio- oraz długoterminowej. s. 11-17. Warszawa: IERiGŻ-PIB.

Józwiak, W. (2014). Rozwój krajowych przedsiębiorstw rolnych osób fizycznych w świetle idei , spirali wzrostu”. Warszawa: IERiGŻ-PIB.

Kociszewski, K. (2014). Ekologiczne aspekty zmian Wspólnej Polityki Rolnej a zrównoważony rozwój polskiego rolnictwa. W: Zegar, J.S. (red.), Z badań nad rolnictwem społecznie zrównoważonym (23), (s. 147-151). Warszawa: IERIGZ-PIB.

Kwasek, M. (red.). (2013). Popyt na żywność ekologiczną. W: Z badań nad rolnictwem społecznie zrównoważonym (21), (s. 24-30). Warszawa: IERiGŻ-PIB.

Kryteria rolnictwa ekologicznego Stowarzyszenia Ekoland. Pobrane z: www.ekoland.pl.

Nachtman, G. (2014). Konkurencyjność ekologicznych gospodarstw roślinnych na tle gospodarstw prowadzących produkcję z udziałem zwierząt. Zagadnienia Ekonomiki Rolnej, nr 4, s. 131-144.

Nachtman, G. (2015). Gospodarstwa łączące ekologiczne i konwencjonalne metody produkcji na tle ekologicznych. Zagadnienia Ekonomiki Rolnej, nr 3, s. 129-148.

Nachtman, G., Puchalska, M. (2014). Wyniki Standardowe 2013 uzyskane przez ekologiczne gospodarstwa rolne. Część I. Wyniki Standardowe. Warszawa.

Pawlewicz, A., Szamrowski, P. (2014). Funkcjonowanie i rozwój rynku ekologicznych surowców żywnościowych w nowej perspektywie finansowej w latach 2014-2020. Wieś i Rolnictwo, nr 3, s. 184.

Program Rozwoju Obszarów Wiejskich 2014-2020. Pobrane z: www.minrol.gov.pl/

Ramowy Plan Działań dla Żywności i Rolnictwa Ekologicznego w Polsce na lata 2014-2020. Pobrane z: www.minrol.gov.pl/

Raport o stanie rolnictwa ekologicznego w Polsce w latach 2013-2014. (2015). Warszawa: IJHARS.

Rozporzadzenie Rady (WE) nr 834/2007 z dnia 28 czerwca 2007 r. w sprawie produkcji ekologicznej i znakowania produktów ekologicznych (Dz.Urz. UE L 189 z 20.07.2007, z późn. zm.).

www.portalspozywczy.pl/owoce-warzywa/wiadomosci/ekspert-w-2015-r-wartosc-rynkuzywnosci-ekologicznej-wyniesie-ok-700-mln-zl,88832.html.

www.ijhar-s.gov.pl/index.php/raporty-i-analizy.html. 
Zegar, J.S. (2009). Struktura polskiego rolnictwa rodzinnego pod koniec pierwszej dekady XXI wieku. Warszawa: IERiGŻ-PIB.

Ziętara, W. (2012). Pozycja konkurencyjna polskich gospodarstw rolnych w procesie integracji i globalizacji. Journal of Agribusiness and Rural Development, 2(24), s. 299-301.

GRAŻYNA NACHTMAN

Institute of Agricultural and Food Economics

- National Research Institute

Warsaw

ECONOMIC SUSTAIANABILITY OF ORGANIC FARMS IN 2010-2013

\section{Summary}

In line with the "Condition of organic farming in Poland.The report 2013-2014", issued by the Main Inspectorate of the Agricultural and Food Quality Inspection (www.ijhar-s.gov.pl), production solely under the organic system was carried out at that time by $67 \%$ and $60 \%$ of organic farms, respectively. The remaining share are entities producing under both organic and conventional methods. According to research, held under the Polish FADN, these farms are highly varied in organisational, production and economic terms. Farms using solely organic methods are distinguished by more holistic approach to executed farming activities, they are also more reliable as regards the quality of manufactured organic food, but they achieve poorer economic results. This is evidenced in the following paper discussing the organisation, production and economic results of such farms grouped according to the size of UAA. Research proved that their production effects over a few years were fairly similar and dropped along with an increase in the area of farms but, at the same time, production intensity dropped. Very poor soil quality also constrained production. The analysis showed that these farms are weak in terms of production and economy, highly dependent on subsidies and rather unlikely to develop in the coming years.

Key words: organic farm, organic production system, organic farming, organic production intensity, organic subsidies, production efficiency, income, organic food market, land productivity

Zaakceptowano do druku - Accepted for print: 03.12.2015. 